\section{Body mass index in individuals with HIV infection and factors associated with thinness and overweight/obesity}

\author{
Índice de massa corporal em indivíduos com infecção \\ pelo HIV e fatores associados com magreza e \\ sobrepeso/obesidade
}

\author{
1 Universidade Federal de \\ Pernambuco, Recife, Brasil. \\ 2 Centro de Pesquisa Aggeu \\ Magalhães, Fundação \\ Oswaldo Cruz, Recife, Brasil. \\ 3 Instituto de Medicina \\ Integral Prof. Fernando \\ Figueira, Recife, Brasil. \\ ${ }^{4}$ Hospital Correia Picanço, \\ Recife, Brasil. \\ Correspondence \\ C. A. Mariz \\ Programa de Pós-gradução \\ em Ciências da Saúde, \\ Universidade Federal de \\ Pernambuco. \\ Rua de Casa Forte 65, \\ apto. 201, Recife, PE \\ 52061460, Brasil. \\ carollinedearaujo@gmail.com
}

\begin{abstract}
A cross-sectional study was conducted using body mass index (BMI) to estimate the prevalence of thinness and overweight/obesity and associated factors in 2,018 individuals with HIVI AIDS attending health services referral centers. The dependent variable was classified as thinness, overweight/obesity and eutrophy. Multinomial logistic regression analyses were performed considering eutrophy as the reference level. The prevalence of thinness was $8.8 \%$ and of overweight/obesity, 32.1\%. The variables associated with thinness were anemia and CD4 cell count $<200 \mathrm{~mm}^{3}$. The variables associated with risk of overweight/obesity were age $\geq 40$ years and diabetes, and the variables identified as decreasing likelihood of overweight/obesity were having no long-term partner, smoking, presence of an opportunistic disease, anemia, and albumin levels $<3.5 \mathrm{mg} / \mathrm{dL}$. The main nutritional problem observed in this population was overweight and obesity, which were much more prevalent than thinness. Older individuals with diabetes should be targeted for nutritional interventions and lifestyle changes.
\end{abstract}

Body Mass Index; HIV Infections; Acquired Immunodeficiency Syndrome
Carolline de Araújo Mariz ${ }^{1}$

Maria de Fátima P. Militão de Albuquerque ${ }^{2}$ Ricardo Arraes de Alencar Ximenes 1 Heloísa Ramos Lacerda de Melo 1 Francisco Bandeira 1 Thaís Gelenske Braga e Oliveira ${ }^{3}$ Érico Higino de Carvalho 3 Adriana Paula da Silva 4 Demócrito de Barros Miranda Filho ${ }^{1}$

\section{Introduction}

Since the introduction of highly active antiretroviral therapy (HAART), AIDS is no longer a terminal illness with rapid progression and high lethality, and has become a chronic disease 1 . However, the use of antiretroviral therapy has led to the emergence of long term co-morbidities, including metabolic changes 2,3,4,5,6,7,8.

Recent studies have demonstrated increasing prevalence of overweight/obesity in the HIVpositive population, with rates paralleling those observed in the general population 9,10,11,12,13,14 . Some studies of the nutritional profile of HIV-infected patients since the introduction of HAART have been carried out in Brazil, with relatively small samples $(\mathrm{n}<400)$ 9,12,13,14. The results have pointed to overweight/obesity rates by body mass index (BMI) in excess of $30 \%$.

The World Health Organization (WHO) suggests the following classification by BMI values: thinness $\left(<18.5 \mathrm{~kg} / \mathrm{m}^{2}\right)$; eutrophy $\left(18.5-24.9 \mathrm{~kg} / \mathrm{m}^{2}\right)$; overweight $\left(25-29.9 \mathrm{~kg} / \mathrm{m}^{2}\right)$; obesity $(30-39.9 \mathrm{~kg} /$ $\left.\mathrm{m}^{2}\right)$ and morbid obesity $\left(>40 \mathrm{~kg} / \mathrm{m}^{2}\right)^{15}$. These cutoff points are based on statistical analysis and the extremes of normal nutrition - thinness and overweight/obesity - are associated with greater risk of developing chronic diseases that have major public health impacts 16 .

The nutritional changes experienced by individuals living with HIV/AIDS seem to be related both to the recent use of HAART and to the di- 
etary patterns and habits of each population 17 . Therefore, this study aims to estimate the prevalence of thinness and overweight/obesity in the HAART era, and to identify related factors in patients with HIV/AIDS in follow-up by referral health services in Pernambuco State, Brazil. There are no published studies on the BMI profile of people living with HIV/AIDS in Pernambuco State, which currently has the highest incidence rate $(18.7$ per 100,000$)$ of reported AIDS cases in the Northeastern Region 18.

\section{Method}

This is a cross-sectional study of HIV/AIDS patients of both sexes attending two health service referral centers in Recife, Pernambuco, in the Northeast region of Brazil, between June 2007 and October 2009. These two health centers - Correia Picanço Hospital and Oswaldo Cruz University Hospital - are responsible for about $75 \%$ of care for people living with HIV/AIDS in Pernambuco.

Study participants were those who agreed to take part and signed a consent form addressing the ethical aspects of the research 19. Only patients aged 18 years old or more were included in the study. Those patients who did not reside in Pernambuco State were excluded.

This study was approved by the research ethics committee at Oswaldo Cruz University Hospital (protocol no. 12/2006).

\section{Data collection}

Data were collected in structured face-to-face interviews by applying a questionnaire specially designed for this research. Additional information was extracted from patient medical records on a form designed for this purpose. The interview was conducted by health personnel previously trained in applying the questionnaire and evaluated periodically by the field work coordinator, while the data from medical records were collected by the main researcher of this study.

\section{Study variables}

The prevalence study was concerned primarily with BMI, according to the classification criteria proposed by the WHO 15. Analysis was based on the following classification: thinness (BMI < $18.5 \mathrm{~kg} / \mathrm{m}^{2}$ ); eutrophy (BMI 18.5-24.9kg/m²); and overweight/obesity (BMI $\geq 25 \mathrm{~kg} / \mathrm{m}^{2}$ ).

Case control analysis was also performed to identify the factors associated with the two outcomes considered - thinness and overweight/ obesity - by comparison with controls (patients classified as eutrophic). The study subjects were weighed using the same anthropometric scale (Filizola S.A., Brazil), which was calibrated periodically during the study period. Height was measured with the patient standing barefoot against a non-extending vertical shaft, with the neck, buttocks and heels touching the shaft.

Biological, socioeconomic, demographic, behavioral, clinical, and laboratory variables potentially associated with the study outcomes were investigated. All individuals who tested positive for HIV, using the ELISA test, immunofluorescence, Western blot or the rapid test, as defined by the Brazilian Ministry of Health, were deemed to be HIV positive. The adapted Centers for Disease Control and Prevention (CDC) criteria and the Rio de Janeiro/Caracas criterion, both adopted by the Brazilian Ministry of Health for individuals aged 13 years older 20 , were used to determine cases of AIDS.

\section{Standardization of techniques}

The EuroSIDA criteria were used for establishing the presence of anemia; i.e., hemoglobin levels below $14 \mathrm{~g} / \mathrm{dL}$ for men and below $12 \mathrm{~g} / \mathrm{dL}$ for women 21 . Serum albumin was processed using Targa 3000 biochemical analyzer and the colorimetric method to determine serum albumin.

Hypoalbuminemia was defined as serum albumin below $3.5 \mathrm{~g} / \mathrm{dL}$, which was the criterion used by Feldman and colleagues 22. The CD4 count was performed by way of flow cytometry using anti-CD4 antibodies labeled with fluorescent dye. The rapid tests used were Rapid Check HIV 1 \& 2 (NDI - Núcleo de Doenças Infecciosas, Vitória, Espírito Santo, Brazil) and Teste Rápido - HIV- 1/2 Bio-Manguinhos (Biomanguinhos, Fundação Oswaldo Cruz, Rio de Janeiro, Brazil).

\section{Statistical analysis}

The data were stored in a database created especially for this research, employing Microsoft's FQL program, Excel (Microsoft Corp.). Double data entry using Epi Info software version 6.04 (Centers for Disease Control and Prevention, Atlanta, USA). Stata 9.0 (Stata Corp., College Station, USA) was employed to describe frequencies, calculate averages, and perform univariate and multivariate multinomial analyses.

The magnitude of the associations was expressed in terms of odds ratios (OR). Statistical significance of associations was ascertained using the chi-square test for category variables, with a p-value $<0.05$ and $95 \%$ confidence interval (95\%CI). Multinomial analysis was used because of the interest in studying the two outcomes sepa- 
rately: comparing both thinness and overweight/ obesity with the eutrophic controls. The order in which variables were input for multinomial multivariate analysis was guided by the theoretical model and by the statistical significance of the association given by univariate analysis 23 with $p<0.20$. Variables were retained in the final multivariate model if their association with at least one of the outcomes was statistically significant with $\mathrm{p}<0.05$.

\section{Results}

Prevalence of thinness and overweight/obesity, and study population characteristics

Of the total 2,074 patients eligible for the study, $56(2.7 \%)$ were excluded because they did not live in Pernambuco. Among the 2,018 individuals studied, 1,192 (59\%) were of normal weight and assigned to the control group. The prevalence of thinness was $8.8 \%$ (178), and of overweight/ obesity, $32.1 \%$ (647). The study population was predominantly male $(1,254-62.1 \%)$, and about half $(1,050-52.1 \%)$ were aged between 18 and 39 years.

Stratification by sex showed that, among men, most were eutrophic $(775-61.8 \%)$, and the frequency of overweight/obesity $(363-29 \%)$ was three times higher than the frequency of thinness, $(116-9.2 \%)$. Among women, $54.6 \%$ were eutrophic and the frequency of overweight/ obesity was also higher than thinness (a ratio of 4.5:1).

Obesity and overweight were more frequent among women (37.2\%), and distribution of the three BMI categories by sex differed significantly $(\mathrm{p}<0.001)$.

Most individuals were eutrophic: 638 (60.8\%) of the 18 to 39 year olds and 554 (57.3\%) of the $\geq 40$ year olds. In both age groups, a higher percentage was overweight/obese than thin: among individuals aged 18-39 years old the prevalence of overweight/obesity was $29.2 \%$ (307), and thinness, $10 \%$ (105); among those aged $\geq 40$ years, 340 (35.2\%) were overweight or obese, and 73 (7.6\%), thin. These differences were statistically significant $(<0.05)$.

Levels of plasma albumin were observed in 1,741 (86.3\%) individuals. Serum albumin below $3.5 \mathrm{~g} / \mathrm{dL}$ was found in 91 (5.2\%) and, of these, $67 \%$ were eutrophic and $7.7 \%$ overweight or obese. Of the $1,650(94.7 \%)$ patients with serum albumin of $3.5 \mathrm{~g} / \mathrm{dL}$ or over, 116 (7\%) were thin. The differences in BMI distribution for the two plasma albumin level groups were statistically significant $(<0.001)$ (Table 1).
The CD4 T cell count found 385 (21.4\%) individuals with 200 cells $/ \mathrm{mm}^{3}$ or less. In this group, the percentages of individuals overweight/obese $(79-20.5 \%)$ and thin $(66-17.1 \%)$ were similar. By contrast, among patients with CD4 cell counts $\geq$ 200cells $/ \mathrm{mm}^{3}$, frequency of overweight/obesity (507-35.8\%) was much higher than frequency of thinness $(89-6.3 \%)$.

The population distribution by categories of BMI, and socioecomonic and demographic factors, are presented in Table 2. Most individuals $(74.25 \%)$ reported having non-white skin color, living in the Recife metropolitan area (55.26\%), being literate $(88.72 \%)$, and having been unemployed in the week preceding the interview (73.89\%).

Around a quarter of patients (544-27\%), did not report their monthly income. Of the 1,474 (73\%) who reported an income, 704 (47.8\%) had monthly income of less than one statutory "minimum wage” (R\$ 350.00 or US\$ 191 in 2008).

Strikingly, in this lowest income category, 202 (28.7\%) patients were overweight or obese and 81 (11.5\%) were thin. Among people with incomes $\geq$ 2 minimum wages, representing $12.5 \%$ of those who reported income, overweight/obesity was observed in 57 (31\%) subjects, and thinness in 7 (3.8\%). Most participants reported having no steady partner (53.5\%). In this group, $61.9 \%$ were eutrophic, $10.2 \%$ thin and $27.9 \%$ overweight/ obese, while BMI distribution among those with steady partners was $55.9 \%$ eutrophic, $7.4 \%$ thin and $36.8 \%$ overweight/obese. The frequency of overweight/obesity was higher among those with no steady partner, and the difference was statistically significant $(\mathrm{p}<0.001)$.

With respect to living habits, $51.6 \%$ of the individuals studied were sedentary, $27 \%$ were smokers, 33.9\% consumed alcohol, and 27.8\% had used illicit drugs at least once in their lives or were current users at the time of interview. Among the nonsmokers, prevalence of overweight/obesity $(34.8 \%)$ was higher than among smokers $(24.6 \%$; $\mathrm{p}<0.001)$. The prevalence of overweight/obesity was $34.1 \%$ among non-drug users, and $26.6 \%$ among users $(\mathrm{p}<0.05)$.

Of the sedentary individuals, $11 \%$ were found to be thin, $30.3 \%$ overweight/obese, and $58.7 \%$ eutrophic. The difference in frequency distribution of thinness, eutrophy and overweight/obesity was statistically significant for the following variables: sedentary lifestyle $(p<0.05)$, smoking ( $\mathrm{p}<0.001)$, alcohol consumption $(\mathrm{p}<0.001)$, and illicit drug use $(\mathrm{p}<0.05)$ (Table 3$)$.

With regard to clinical characteristics, it was found that $82.9 \%$ of all the patients had been HIV positive for less than three years, and $86.4 \%$ had AIDS. Among the individuals studied, $82.3 \%$ were 
Univariate analysis of association between biological factors and body mass index in HIV/AIDS patients. Recife, Pernambuco State, Brazil, $2007-2009$.

\begin{tabular}{|c|c|c|c|c|c|c|c|c|c|c|}
\hline \multirow[t]{3}{*}{ Variables } & \multicolumn{6}{|c|}{ BMI classification } & \multirow{2}{*}{\multicolumn{2}{|c|}{ In relation to thinness * }} & \multirow{2}{*}{\multicolumn{2}{|c|}{$\begin{array}{l}\text { In relation to overweight/ } \\
\text { obesity * }\end{array}$}} \\
\hline & \multicolumn{2}{|c|}{ Eutrophic } & \multicolumn{2}{|c|}{ Thinness } & \multicolumn{2}{|c|}{ Overweight/Obesity } & & & & \\
\hline & $\mathrm{n}$ & $\%$ & n & $\%$ & $\mathrm{n}$ & $\%$ & OR $(95 \% \mathrm{Cl})$ & $\mathrm{p}$-value & OR $(95 \% \mathrm{Cl})$ & p-value \\
\hline \multicolumn{11}{|l|}{ Age (years) } \\
\hline $18-39$ & 638 & 60.8 & 105 & 10.0 & 307 & 29.2 & 1.0 & - & 1.0 & - \\
\hline$\geq 40$ & 554 & 57.3 & 73 & 7.6 & 340 & 35.2 & $0.80(0.58-1.10)$ & 0.173 & $1.27(1.05-1.54)$ & $<0.05 * \star$ \\
\hline \multicolumn{11}{|l|}{ Sex } \\
\hline Male & 775 & 61.8 & 116 & 9.2 & 363 & 29.0 & 1.0 & - & 1.0 & - \\
\hline Female & 417 & 54.6 & 63 & 8.2 & 284 & 37.2 & $1.01(0.72-1.40)$ & 0.956 & $1.45(1.19-1.76)$ & $<0.001^{\star *}$ \\
\hline \multicolumn{11}{|l|}{ Albumin } \\
\hline$\geq 3.5 \mathrm{~g} / \mathrm{dL}$ & 967 & 58.6 & 116 & 7.0 & 567 & 34.4 & 1.0 & - & 1.0 & - \\
\hline$<3.5 \mathrm{~g} / \mathrm{dL}$ & 61 & 67.0 & 23 & 25.3 & 7 & 7.7 & $3.14(1.78-5.26)$ & $<0.001 * *$ & $0.19(0.09-0.43)$ & $<0.001$ ** \\
\hline \multicolumn{11}{|l|}{ Hemoglobin } \\
\hline Normal & 717 & 56.4 & 81 & 6.4 & 473 & 37.2 & 1.0 & - & 1.0 & - \\
\hline Anemia & 475 & 64.0 & 98 & 13.1 & 174 & 23.3 & $1.82(1.33-2.50)$ & $<0.001 \star \star \star$ & $0.55(0.45-0.68)$ & $<0.001$ ** \\
\hline \multicolumn{11}{|l|}{ Current CD4 } \\
\hline$\geq 200$ cells $/ \mathrm{mm}^{3}$ & 820 & 57.9 & 89 & 6.3 & 507 & 35.8 & 1.0 & - & 1.0 & - \\
\hline$<200$ cells $/ \mathrm{mm}^{3}$ & 240 & 62.3 & 66 & 17.1 & 79 & 20.5 & $2.53(1.78-3.59)$ & $<0.001 * \star$ & $0.53(0.40-0.70)$ & $<0.001$ ** \\
\hline
\end{tabular}

BMI: body mass index; OR: odds ratio; $95 \% \mathrm{Cl}$ : 95\% confidence interval.

* Eutrophic BMI as reference;

** Statistically significant association $(p<0.05)$.

undergoing antiretroviral therapy (ARV). Among ARV users, the frequency of overweight/obese was $32.4 \%$ and the frequency of thinness was $7.8 \%$. A record of an opportunistic disease within the past three months was found in $46.2 \%$ of the study population. Of these, $62 \%$ were eutrophic, $11.8 \%$ were thin and $26.2 \%$, overweight/obese (Table 4).

\section{Multinomial univariate analysis}

Univariate multinomial regression analysis showed that albumin level $<3.5 \mathrm{~g} / \mathrm{dL}$ was associated with $\mathrm{BMI}<18.5 \mathrm{~kg} / \mathrm{m}^{2}$ and with $\mathrm{BMI} \geq$ $25 \mathrm{~kg} / \mathrm{m}^{2}$. The presence of anemia was associated with $\mathrm{BMI}<18.5 \mathrm{~kg} / \mathrm{m}^{2}$ and $\mathrm{BMI} \geq 25 \mathrm{~kg} / \mathrm{m}^{2}$. Table 1 shows the statistically significant association between CD4 cell count $<200$ and both thinness and overweight/obesity. The univariate multinomial analysis also showed a statistically significant association between monthly income $\geq 2$ minimum wages and BMI $<18.5 \mathrm{~kg} / \mathrm{m}^{2}$. Not having a steady partner was inversely associated with $\mathrm{BMI} \geq 25 \mathrm{~kg} / \mathrm{m}^{2}$.

The association between BMI and opportunistic disease was statistically significant for both thinness and overweight/obesity. Occurrence of lymphoma or another cancer (2.8\%) and occurrence of cirrhosis $(2.9 \%)$ were not associated with thinness or overweight/obesity. On the other hand, diabetes $(3.9 \%)$ was associated with overweight and obesity (Table 4).

\section{Multinomial multivariate analysis}

In multinomial multivariate logistic regression analysis, eight variables showing statistically significant association with at least one of the outcomes (thinness or overweight/obesity) in patients with HIV/AIDS were retained in the final model.

Table 5 shows the variables associated with thinness: CD4 $\mathrm{T}$ cell count $<200$ cells $/ \mathrm{mm}^{3}$ and anemia. The variables remaining in the final model with an independent association with overweight/obesity were age $\geq 40$ years and diabetes mellitus. Variables inversely associated with overweight/obesity were having a steady partner, smoking, having an opportunistic disease, serum albumin $<3.5 \mathrm{~g} / \mathrm{dL}$ and anemia. 
Univariate analysis of association between socioeconomic and demographic factors and body mass index in HIV/AIDS patients. Recife, Pernambuco State, Brazil, 2007-2009.

\begin{tabular}{|c|c|c|c|c|c|c|c|c|c|c|}
\hline \multirow[t]{3}{*}{ Variables } & \multicolumn{6}{|c|}{ BMI classification } & \multirow{2}{*}{\multicolumn{2}{|c|}{ In relation to thinness * }} & \multirow{2}{*}{\multicolumn{2}{|c|}{$\begin{array}{l}\text { In relation to overweight/ } \\
\text { obesity * }\end{array}$}} \\
\hline & \multicolumn{2}{|c|}{ Eutrophic } & \multicolumn{2}{|c|}{ Thinness } & \multicolumn{2}{|c|}{ Overweight/Obesity } & & & & \\
\hline & n & $\%$ & n & $\%$ & n & $\%$ & OR (95\%Cl) & p-value & OR $(95 \% \mathrm{Cl})$ & p-value \\
\hline \multicolumn{11}{|l|}{ Skin color } \\
\hline White & 304 & 58.6 & 39 & 7.5 & 176 & 33.9 & 1.0 & - & 1.0 & - \\
\hline Non-white & 887 & 59.2 & 140 & 9.4 & 470 & 31.4 & $1.23(0.84-1.79)$ & 0.283 & $0.91(0.73-1.13)$ & 0.423 \\
\hline \multicolumn{11}{|l|}{ Steady partner } \\
\hline Yes & 524 & 55.9 & 69 & 7.4 & 345 & 36.8 & 1.0 & - & 1.0 & - \\
\hline No & 667 & 61.9 & 110 & 10.2 & 301 & 27.9 & $1.11(0.95-1.31)$ & 0.171 & $0.82(0.75-0.91)$ & $<0.001$ ** \\
\hline \multicolumn{11}{|l|}{ City } \\
\hline Recife & 463 & 56.9 & 77 & 9.5 & 273 & 33.6 & 1.0 & - & 1.0 & - \\
\hline Recife & 178 & 59.1 & 22 & 7.3 & 101 & 33.6 & $0.74(0.45-1.23)$ & 0.249 & $0.96(0.72-1.28)$ & 0.793 \\
\hline \multicolumn{11}{|l|}{ Metropolitan } \\
\hline \multicolumn{11}{|l|}{ Area } \\
\hline Other cities & 550 & 61.0 & 79 & 8.8 & 273 & 30.3 & $0.86(0.61-1.21)$ & 0.395 & $0.84(0.68-1.03)$ & 0.105 \\
\hline \multicolumn{11}{|l|}{ Can read and write } \\
\hline Yes & 1048 & 58.7 & 160 & 9.0 & 578 & 32.3 & 1.0 & - & 1.0 & - \\
\hline No & 141 & 62.1 & 19 & 8.4 & 67 & 29.5 & $0.88(0.53-1.46)$ & 0.629 & $0.86(0.63-1.17)$ & 0.343 \\
\hline \multicolumn{11}{|l|}{ Educational level } \\
\hline $\begin{array}{l}\text { High School and } \\
\text { beyond }\end{array}$ & 501 & 58.9 & 74 & 8.7 & 275 & 32.4 & 1.0 & - & 1.0 & - \\
\hline $\begin{array}{l}\text { Primary School } \\
\text { only }\end{array}$ & 671 & 58.9 & 103 & 9.0 & 365 & 32.1 & $1.03(0.75-1.43)$ & 0.814 & $0.99(0.81-1.20)$ & 0.927 \\
\hline \multicolumn{11}{|l|}{ Work } \\
\hline Yes & 300 & 57.6 & 36 & 6.9 & 185 & 35.5 & 1.0 & - & 1.0 & - \\
\hline No & 879 & 59.6 & 142 & 9.6 & 454 & 30.8 & $1.34(0.91-1.98)$ & 0.134 & $0.83(0.67-1.03)$ & 0.107 \\
\hline \multicolumn{11}{|l|}{ Income (in minimum } \\
\hline \multicolumn{11}{|l|}{ wages) } \\
\hline$<1$ & 421 & 59.8 & 81 & 11.5 & 202 & 28.7 & 1.0 & - & 1.0 & - \\
\hline 1 to $<2$ & 338 & 57.7 & 51 & 8.7 & 197 & 33.6 & $0.78(0.53-1.14)$ & 0.208 & $1.21(0.95-1.54)$ & 0.117 \\
\hline$\geq 2$ & 120 & 65.2 & 07 & 3.8 & 57 & 31.0 & $0.55(0.36-0.82)$ & $<0.05 * \star$ & $0.99(0.83-1.19)$ & 0.956 \\
\hline Not given & 313 & 57.5 & 40 & 7.3 & 191 & 35.1 & 0.87 (0.76-0.99) & $<0.05^{\star \star}$ & $1.08(0.99-1.17)$ & 0.055 \\
\hline
\end{tabular}

BMI: body mass index; OR: odds ratio; 95\% $\mathrm{Cl}$ : 95\% confidence interval.

* Eutrophic BMI as reference;

** Statistically significant association $(p<0.05)$.

\section{Discussion}

In the population studied, thinness was found in $8.8 \%$ of individuals and overweight/obesity in $32.1 \%$. Eutrophic individuals accounted for $59.1 \%$.

The variables directly associated with overweight/obesity were found to be age $\geq 40$ years and diabetes, while not having a steady partner, being a smoker, having had an opportunistic disease, serum albumin $<3.5 \mathrm{mg} / \mathrm{dL}$ and anemia were inversely associated. CD4 count of < 200 cells $/ \mathrm{mm}^{3}$ and anemia were associated with thinness.

Obesity is prevalent around the world, and this has been widely reported in the literature $16,24,25$. In Brazil, the last household survey on risk behaviors and self-reported morbidity for non-communicable diseases and injuries found increased prevalence of obesity. This survey was 
Table 3

Univariate analysis of association between behavioral factors and body mass index in HIV/AIDS patients. Recife, Pernambuco State, Brazil, 2007-2009.

\begin{tabular}{|c|c|c|c|c|c|c|c|c|c|c|}
\hline \multirow[t]{3}{*}{ Variables } & \multicolumn{6}{|c|}{ BMI classification } & \multirow{2}{*}{\multicolumn{2}{|c|}{ In relation to thinness * }} & \multirow{2}{*}{\multicolumn{2}{|c|}{$\begin{array}{c}\text { In relation to } \\
\text { overweight/obesity * }\end{array}$}} \\
\hline & \multicolumn{2}{|c|}{ Eutrophic } & \multicolumn{2}{|c|}{ Thinness } & \multicolumn{2}{|c|}{ Overweight/Obesity } & & & & \\
\hline & $\mathbf{n}$ & $\%$ & $\mathrm{n}$ & $\%$ & $\mathrm{n}$ & $\%$ & OR $(95 \% \mathrm{Cl})$ & p-value & OR $(95 \% \mathrm{Cl})$ & p-value \\
\hline \multicolumn{11}{|l|}{ Sedentary } \\
\hline No & 581 & 59.5 & 64 & 6.5 & 332 & 34.0 & 1.0 & - & 1.0 & - \\
\hline Yes & 611 & 58.7 & 115 & 11.0 & 315 & 30.3 & $1.71(1.23-2.37)$ & $<0.05^{* \star}$ & $0.90(0.74-1.09)$ & 0.292 \\
\hline \multicolumn{11}{|l|}{ Smoker } \\
\hline No & 831 & 56.5 & 128 & 8.7 & 512 & 34.8 & 1.0 & - & 1.0 & - \\
\hline Yes & 360 & 66 & 51 & 9.4 & 134 & 24.6 & $0.92(0.65-1.30)$ & 0.637 & $0.60(0.48-0.76)$ & $<0.001 * \star$ \\
\hline \multicolumn{11}{|c|}{$\begin{array}{l}\text { Alcohol } \\
\text { consumption }\end{array}$} \\
\hline No & 747 & 56.8 & 145 & 11.0 & 423 & 32.2 & 1.0 & - & 1.0 & - \\
\hline Yes & 429 & 63.6 & 30 & 4.4 & 216 & 32.0 & $0.36(0.24-0.54)$ & $<0.001 * *$ & $0.89(0.72-1.09)$ & 0.255 \\
\hline \multicolumn{11}{|l|}{ Illicit drugs } \\
\hline No & 826 & 56.7 & 133 & 9.1 & 497 & 34.1 & 1.0 & - & 1.0 & - \\
\hline Yes & 365 & 65.2 & 46 & 8.2 & 149 & 26.6 & $0.78(0.54-1.11)$ & 0.179 & $0.67(0.54-0.84)$ & $<0.05$ ** \\
\hline
\end{tabular}

BMI: body mass index; OR: odds ratio; $95 \% \mathrm{Cl}$ : 95\% confidence interval.

* Eutrophic BMI as reference;

** Statistically significant association $(p<0.05)$.

conducted between 2002 and 2003 in the population aged over 15 years, in 15 state capitals and the Federal District 11 .

Changes have been reported in the nutritional profile of individuals with HIV since the introduction of HAART, with an increasing prevalence of obesity and a decrease in thinness 9,10,12,13. Some studies have shown that rates of overweight and obesity found in people living with HIV/AIDS do not differ from those of the general population $9,10,12,13,16,24,25$.

The first Brazilian study of the nutritional status of a population with HIV/AIDS on antiretroviral therapy was conducted in São Paulo, and showed $30.5 \%$ of them to be overweight/obese 9 . Leite \& Sampaio 12 found the proportion of overweight/obesity in people with HIV/AIDS in Rio de Janeiro to be approximately $50 \%$. Although these studies used much smaller samples ( $\mathrm{n}<$ $400)$ compared than in the present study $(2,018)$, the results reported here show a prevalence of overweight/obesity (32.1\%) very similar to that found by the São Paulo study.

The prevalence of overweight and obesity in the general population tends to increase with age. Gigante et al. 26 conducted a cross-sectional study involving 1,035 individuals and found that the prevalence of obesity in the adult population of Pelotas (Rio Grande do Sul State, Brazil) was four times greater in individuals aged over
40 years than in the group aged between 20 and 29 years. The same trend seems to be observed in the HIV-positive population.

The findings of this study demonstrate an association between age $\geq 40$ years and overweight/ obesity. This age group has also been associated with central obesity 13,27.

Some authors have argued that metabolic complications, such as changes in body fat distribution, dyslipidemia and insulin resistance are common in HIV-infected adults on antiretroviral therapy 9,28,29,30, and overweight is an aggravating condition for developing such complications 10 . In this study, the use of HAART ceased to be associated with overweight/obesity in the final multivariate analysis model, possibly because the vast majority of patients were taking HAART (82.3\%).

In the so-called HAART era, diabetes is now found with greater frequency among HIV patients. Brown et al. 31 showed that the incidence of diabetes was four times higher in an HIV-infected population exposed to HAART (mean BMI of $25 \mathrm{~kg} / \mathrm{m}^{2}$ ) than among the uninfected (mean BMI of $26 \mathrm{~kg} / \mathrm{m}^{2}$ ). Our study found a significant association between diabetes and overweight/ obesity, independent of the use of HAART. While the proportion of overweight/obesity is increasing in the HIV-positive population, the incidence and prevalence of diabetes also tends to increase, 
Univariate analysis of association between clinical factors and body mass index in HIV/AIDS patients. Recife, Pernambuco State, Brazil, $2007-2009$.

\begin{tabular}{|c|c|c|c|c|c|c|c|c|c|c|}
\hline \multirow[t]{3}{*}{ Variables } & \multicolumn{6}{|c|}{ BMI classification } & \multirow{2}{*}{\multicolumn{2}{|c|}{ In relation to thinness * }} & \multirow{2}{*}{\multicolumn{2}{|c|}{$\begin{array}{l}\text { In relation to overweight/ } \\
\text { obesity * }\end{array}$}} \\
\hline & \multicolumn{2}{|c|}{ Eutrophic } & \multicolumn{2}{|c|}{ Thinness } & \multicolumn{2}{|c|}{ Overweight/Obesity } & & & & \\
\hline & $\mathrm{n}$ & $\%$ & $\mathrm{n}$ & $\%$ & n & $\%$ & OR $(95 \% \mathrm{Cl})$ & $p$-value & OR $(95 \% \mathrm{Cl})$ & $p$-value \\
\hline \multicolumn{11}{|l|}{ Using antiretroviral therapy } \\
\hline No & 183 & 55.1 & 41 & 12.3 & 108 & 32.5 & 1.0 & - & 1.0 & - \\
\hline Yes & 921 & 59.7 & 121 & 7.8 & 499 & 32.4 & $1.70(1.15-2.51)$ & $<0.05^{\star \star}$ & $1.08(0.84-1.41)$ & 0.522 \\
\hline \multicolumn{11}{|l|}{ Time HIV } \\
\hline$<1$ month & 221 & 65.4 & 47 & 13.9 & 70 & 20.7 & 1.0 & - & 1.0 & - \\
\hline$\geq 1$ month and $<1$ year & 191 & 57.2 & 20 & 6.0 & 123 & 36.8 & $0.70(0.53-0.92)$ & $<0.05^{* *}$ & $1.42(1.19-1.69)$ & $<0.001$ ** \\
\hline$\geq 1$ year and $<3$ years & 567 & 57.7 & 80 & 8.1 & 336 & 34.2 & $0.87(0.76-0.99)$ & $<0.05 * \star$ & $1.23(1.11-1.36)$ & $<0.001 * *$ \\
\hline$\geq 3$ years & 199 & 58.7 & 23 & 6.8 & 117 & 34.5 & $0.85(0.75-0.98)$ & $<0.05^{\star \star}$ & $1.16(1.06-1.27)$ & $<0.05^{\star \star}$ \\
\hline \multicolumn{11}{|l|}{ AIDS } \\
\hline No & 141 & 54.2 & 11 & 4.2 & 108 & 41.5 & 1.0 & - & 1.0 & - \\
\hline Yes & 985 & 59.4 & 154 & 9.3 & 520 & 31.3 & $2.00(1.06-3.78)$ & $<0.05^{\star \star}$ & $0.68(0.52-0.90)$ & $<0.05^{\star \star}$ \\
\hline \multicolumn{11}{|l|}{ Opportunistic disease (last } \\
\hline \multicolumn{11}{|l|}{3 months) } \\
\hline No & 612 & 56.6 & 66 & 6.1 & 403 & 37.3 & 1.0 & - & 1.0 & - \\
\hline Yes & 575 & 62.0 & 110 & 11.8 & 243 & 26.2 & $1.77(1.28-2.45)$ & $<0.05^{\star \star}$ & $0.64(0.52-0.78)$ & $<0.001$ ** \\
\hline \multicolumn{11}{|l|}{ Lymphoma } \\
\hline No & 1,150 & 59.0 & 175 & 9.0 & 624 & 32.0 & 1.0 & - & 1.0 & - \\
\hline Yes & 32 & 57.1 & 03 & 5.4 & 21 & 37.5 & $0.61(0.18-2.03)$ & 0.427 & $1.20(0.69-2.11)$ & 0.505 \\
\hline \multicolumn{11}{|l|}{ Diabetes } \\
\hline No & 1,116 & 59.5 & 174 & 9.3 & 587 & 31.3 & 1.0 & - & 1.0 & - \\
\hline Yes & 33 & 42.3 & 03 & 3.8 & 42 & 53.8 & $0.58(0.17-1.92)$ & 0.375 & $2.42(1.51-3.85)$ & $<0.001$ ** \\
\hline \multicolumn{11}{|l|}{ Cirrhosis } \\
\hline No & 1,139 & 58.9 & 170 & 8.8 & 626 & 32.3 & 1.0 & - & 1.0 & - \\
\hline Yes & 34 & 58.6 & 07 & 12.1 & 17 & 29.3 & $1.37(0.60-3.16)$ & 0.447 & $0.91(0.50-1.64)$ & 0.753 \\
\hline
\end{tabular}

BMI: body mass index; OR: odds ratio; $95 \% \mathrm{Cl}$ : $95 \%$ confidence interval.

* Eutrophic BMI as reference;

** Statistically significant association $(p<0.05)$.

leading to a cycle that feeds back: diabetics gain more weight, and those who gain more weight tend to stay diabetic.

Before HAART, weight loss and malnutrition were frequent, and wasting syndrome, a relatively common complication of advanced stages of HIV infection, came to be considered an AIDS-defining event from 1987 onwards 32,33. In the United States, one of the effects of reduced morbidity following the use of antiretroviral therapy, and especially HAART, was a decline in the incidence of wasting syndrome between 1992 and 1999, with a more pronounced trend after the end of 1995 34, which coincides with the beginning of the HAART era.

Despite these changes, thinness continues to be reported in studies of AIDS. Recently, Sieleunou et al. 35 studied a population of 2161 HIV- positive individuals on HAART living in Cameroon, and found a percentage of $56 \%$ of thinness.

Furthermore, it can be suggested that the use of HAART alone is not a determining factor for change in the nutritional profile of these patients, despite the direct association with changes in adipose tissue and insulin resistance. In fact, the nutritional changes experienced by the individual with HIV/AIDS would also be expected to vary with dietary and genetic differences within each population 17 .

The frequency of thinness found in the present study (8.8\%) differs from that found by Sieleunou et al. 35. The low prevalence of underweight individuals in the study population may be due to the fact that most of the subjects studied were receiving HAART and had good immune control. The mean CD4 T cell found in this study 
Multivariate analysis of association between biological, socioeconomic, demographic, behavioral and clinical factors with body mass index classification in HIV/AIDS patients. Recife, Pernambuco State, Brazil, 2007-2009.

\begin{tabular}{|c|c|c|c|c|}
\hline \multirow[t]{2}{*}{ Variables } & \multicolumn{2}{|c|}{ In relation to thinness * } & \multicolumn{2}{|c|}{ In relation to overweight/obesity * } \\
\hline & OR $(95 \% \mathrm{Cl})$ & p-value & OR $(95 \% \mathrm{Cl})$ & p-value \\
\hline \multicolumn{5}{|l|}{ Age (years) } \\
\hline $18-39$ & 1.0 & - & 1.0 & - \\
\hline$\geq 40$ & $0.80(0.54-1.19)$ & 0.275 & $1.30(1.03-1.63)$ & $<0.05 * \star$ \\
\hline \multicolumn{5}{|l|}{ Steady partner } \\
\hline Yes & 1.0 & - & 1.0 & - \\
\hline No & $1.09(0.89-1.33)$ & 0.394 & $0.82(0.73-0.92)$ & $<0.05 * *$ \\
\hline \multicolumn{5}{|l|}{ Smoker } \\
\hline No & 1.0 & - & 1.0 & - \\
\hline Yes & $1.08(0.70-1.67)$ & 0.723 & $0.58(0.44-0.75)$ & $<0.001 \star \star$ \\
\hline \multicolumn{5}{|l|}{ Diabetes } \\
\hline No & 1.0 & - & 1.0 & - \\
\hline Yes & $0.35(0.05-2.69)$ & 0.317 & $2.41(1.41-4.14)$ & $<0.05^{* *}$ \\
\hline \multicolumn{5}{|c|}{ Opportunistic disease } \\
\hline \multicolumn{5}{|l|}{ (last 3 months) } \\
\hline No & 1.0 & - & 1.0 & - \\
\hline Yes & $1.30(0.88-1.94)$ & 0.190 & $0.67(0.53-0.84)$ & $<0.05^{\star \star}$ \\
\hline \multicolumn{5}{|l|}{ Current CD4 } \\
\hline$\geq 200 \mathrm{cells} / \mathrm{mm}^{3}$ & 1.0 & - & 1.0 & - \\
\hline$<200$ cells $/ \mathrm{mm}^{3}$ & $2.13(1.41-3.24)$ & $<0.001$ ** & $0.73(0.53-0.99)$ & 0.050 \\
\hline \multicolumn{5}{|l|}{ Albumin } \\
\hline$\geq 3.5 \mathrm{~g} / \mathrm{dL}$ & 1.0 & - & 1.0 & - \\
\hline$<3.5 \mathrm{~g} / \mathrm{dL}$ & $1.44(0.76-2.71)$ & 0.252 & $0.27(0.12-0.61)$ & $<0.05$ ** \\
\hline \multicolumn{5}{|l|}{ Hemoglobin } \\
\hline Normal & 1.0 & - & 1.0 & - \\
\hline Anemia & $1.78(1.17-2.74)$ & $<0.05^{\star \star}$ & $0.59(0.46-0.76)$ & $<0.001 \star \star$ \\
\hline
\end{tabular}

OR: odds ratio; $95 \% \mathrm{Cl}$ : $95 \%$ confidence interval.

* Eutrophic BMI as reference;

${ }^{* \star}$ Statistically significant association $(p<0.05)$.

was 432.1 cells $/ \mathrm{mm}^{3}$. Rousseau et al. 36, after two assessments of nutritional status in patients before and after HAART use, concluded that the use of antiretrovirals may help prevent weight loss. De Luis et al. 37 found that the average BMI in 119 HIV-infected individuals using HAART was $22.5 \mathrm{~kg} / \mathrm{m}^{2}$.

Low serum albumin has been used as an indicator of malnutrition when assessing nutritional status 38 . In this study, among patients who had serum albumin $(1,741-86.3 \%)$, the vast majority $(94.8 \%)$ had serum albumin levels $\geq 3.5 \mathrm{mg} /$ $\mathrm{dL}$, thus differing from results reported by other authors $39,40,41$.

Low levels of albumin $(<3.5 \mathrm{mg} / \mathrm{dL})$ were statistically associated with the two outcomes in opposite directions: directly associated with thin- ness and inversely associated with overweight/ obesity.

A recent study found contradictorily increasing trends in prevalence of both overweight/obesity and anemia in Brazil 42 . Its authors identified anemia, for its magnitude, as the principal deficiency problem in Brazil. For Mocroft et al. 21, anemia is a relatively common clinical condition in HIV-positive individuals, owing to the specific effects of the infection, the use of antiretroviral drugs, and even insufficient food intake. In the present study, anemia was directly associated with thinness, and inversely with overweight/ obesity.

Understanding the association between anemia and thinness is relatively easy, since the association between protein-calorie malnutrition and 
anemia in HIV-positive individuals is already well established in the literature $39,43,44$. However, it would appear to be more difficult to understand the association between anemia and overweight/ obesity in this same population. As of the time of writing, we are aware of no studies addressing the association between obesity, anemia and HIV/AIDS. However, we can interpret our findings in the context of what is already established: i.e., that the risk factors for the development of overweight and obesity are the nutritional factors involved in a high calorie diet, characterized by excessive consumption of sugars, animal fats, saturated fatty acids and trans fat, which do not constitute a healthy enough diet to maintain normal levels of hemoglobin in the blood.

We found a strong association between CD4 cell count $<200$ cells $/ \mathrm{mm}^{3}$ and thinness. Moreover, the association between levels of CD4 < 200cells $/ \mathrm{mm}^{3}$ and overweight/obesity was not statistically significant. It is known that immune depletion resulting from HIV/AIDS leads to malnutrition, which in turn exacerbates the immune dysfunction 45 .

In the study population, not having a steady partner was inversely associated with overweight/obesity. There seems to be an association between overweight/obesity and having social support - represented in this study by the presence of a steady partner - which is no different among HIV-positive individuals and the general population. However, it should be emphasized that no studies were found on the possible association between overweight/obesity and having a steady partner (a proxy variable for social support) in people living with HIV/AIDS.

Other socio-economic and demographic variables were studied, such as self-reported skin color, city of residence, education, employment, and economic income. However, no associations were found between them and thinness and/or overweight/obesity.

Smoking is one of the most serious public health problems worldwide, and has become an epidemic affecting not only people's health, but also national economies and the environment. In agreement with the studies of Amorosa et al. 46 and Boodram et al. ${ }^{47}$, the present study found that smoking was inversely associated with overweight/obesity.
The occurrence of opportunistic infections diminished significantly after the introduction of antiretroviral therapy 10,48 , and a statistically significant association has already been demonstrated between the occurrence of opportunistic infections and a reduction in body weight 17 . This evidence could explain the findings to the effect that the occurrence of opportunistic infections in the past three months was inversely associated with overweight/obesity.

One limitation of this study is the possible presence of "reverse causality" in some of the associations studied. However, the results are important because they identify factors associated with thinness and overweight/obesity in a large population of people living with HIV/AIDS. Furthermore, they draw attention to a likely transition in the nutritional profile of patients with HIV/AIDS.

Early in the epidemic, before the advent of HAART, there was a high prevalence of thinness. Now we are seeing a shift away from the old pattern of BMI categories, with high frequencies of overweight and obesity in people living with HIV/AIDS. It is possible that very soon, new drugs with fewer adverse effects in terms of metabolic changes that can lead to overweight/obesity will be developed, eventually leading to a decrease in the prevalence of overweight/obesity in this population. A further, more subjective question could be raised regarding the stigma attached to HIV/AIDS. The fact that wasting syndrome has been so strongly linked to AIDS may lead individuals infected with HIV to adopt a high-calorie diet and avoid physical exertion, as a reaction to the stigma associated with weight loss.

These results indicate the importance of incorporating dieticians into the routine of referral services as a way of providing more comprehensive care for individuals with HIV/AIDS. This will make it possible to implement preventive actions and adequate monitoring of patients' nutritional status, through not only BMI, but other anthropometric data (triceps skinfold, arm circumference, and waist and hip measurements), along with biochemical, clinical and dietary factors. 


\section{Resumo}

Estudo seccional para estimar a prevalência de magreza e sobrepeso/obesidade e fatores associados em 2.018 indivíduos com HIVIAIDS, atendidos em serviços de referência em Recife, Pernambuco, Brasil, utilizando o índice de massa corporal. A variável dependente foi classificada como magreza, sobrepeso/obesidade e eutrofia. Realizou-se análise de regressão logística multinomial considerando-se como referência os eutróficos. A prevalência de magreza foi de $8,8 \%$ e a de sobrepeso/obesidade de 32,1\%. Permaneceram associados à magreza ter anemia e contagem de células TCD4 $<200 \mathrm{~mm}^{3}$. Os fatores associados à maior chance de sobrepeso/obesidade foram: idade $\geq 40$ anos e presença de diabetes, e aqueles inversamente associados com sobrepeso/obesidade: não ter companheiro fixo, tabagismo, história recente de doença oportunista, anemia e níveis de albumina $<3,5 \mathrm{mg} / \mathrm{dL}$. O principal desvio nutricional observado foi o sobrepeso/obesidade, superando a magreza. Os indivíduos mais velhos com diabetes devem ser alvos de intervenções nutricionais e de estilo de vida.

Índice de Massa Corporal; Infecções por HIV; Síndrome de Imunodeficiência Adquirida

\section{Contributors}

C. A. Mariz and M. F. P. M. Albuquerque participated in the literature review, study planning, data analysis, discussion of results, and organization and final wording of this article. R. A. A. Ximenes and H. R. L. Melo contributed to planning the research, discussing the results and reviewing the final text. F. Bandeira took part in discussing the results and reviewing the final text. T. G. B. Oliveira and E. H. Carvalho participated in the literature review, discussion of the results, and final wording of the article; A. P. Silva, in interpreting the findings; and D. B. Miranda Filho, in the literature review, discussion of the results, and final wording of this article.

\section{Acknowledgement}

This study received financial support from the Ministry of Health Program DST/AIDS/UNESCO (CSV 182/06 Projeto Estudo Clínico-Epidemiológico da Co-Infecção HIVITuberculose em Recife).

\section{References}

1. Programa Nacional de DST e AIDS, Secretaria de Vigilância em Saúde, Ministério da Saúde. Recomendações para terapia anti-retroviral em adultos infectados pelo HIV 2008. Brasília: Ministério da Saúde; 2008.

2. Carr A. HIV lipodystrophy: risk factors, pathogenesis, diagnosis and management. AIDS 2003; 17 Suppl 1:S141-8.

3. American Diabetes Association. Position of the American Dietetic Association and Dietitians of Canada: nutrition intervention in the care of persons with human immunodeficiency virus infection. J Am Diet Assoc 2004; 104:1425-41.

4. Madeddu G, Spanu A, Solinas P, Calia GM, Lovigu $\mathrm{C}$, Chessa F, et al. Bone mass loss and vitamin D metabolism impairment in HIV patients receiving highly active antiretroviral therapy. Q J Nucl Med Mol Imaging 2004; 48:39-48.
5. Friis-Moller N, Reiss P, Sabin CA, Weber R, Monforte A, El-Sadr W, et al. Class of antiretroviral drugs and the risk of myocardial infarction. N Engl J Med 2007; 356:1723-35.

6. Dutra CDT, Libonati MF. Abordagem metabólica e nutricional da lipodistrofia em uso da terapia antiretroviral. Rev Nutr 2008; 21:239-46.

7. World Bank/The International Bank for Reconstruction and Development. HIV/AIDS, nutrition and food security: what we can do? A synthesis of international guidance. Washington DC: World Bank; 2007.

8. Grinspoon SK, Grunfeld C, Kotler DP, Currier JS, Lundgren JE, Dubé MP, et al. State of the science conference initiative to decrease cardiovascular risk and increase quality of care for patients living with HIV/AIDS. Circulation 2008; 118:198-210. 
9. Jaime PC, Florindo AA, Latorre MRDO, Brasil BG, Santos ECM, Segurado AAV. Prevalence of overweight and central obesity in HIV/AIDS patients treated with highly active antiretroviral therapy. Rev Bras Epidemiol 2004; 7:65-72.

10. Hendricks KM, Mwamburi DM, Newby PK, Wanke CA. Dietary patterns and health and nutrition outcomes in men living with HIV infection. Am J Clin Nutr 2008; 88:1584-92.

11. Ford ES, Mokdad AH. Epidemiologia da obesidade no hemisfério ocidental. Atlanta: Centers for Disease Control and Prevention; 2008.

12. Leite LHM, Sampaio ABMM. Metabolic abnormalities and overweight in HIV/AIDS persons treated with antiretroviral therapy. Rev Nutr 2008; 21: 277-83.

13. Oliveira OMV, Medeiros RS, Nascimento MAB, Boni MS. Perfil nutricional e fatores de risco para obesidade central de pessoas que vivem com HIV/ AIDS. Comun Ciênc Saúde 2008; 19:305-14.

14. Rocha PB, Schuch I. Perfil alimentar e nutricional dos pacientes HIV positivo atendidos em um serviço público de saúde de Porto Alegre/RS. Nutrire Rev Soc Bras Aliment Nutr 2009; 34:1-15.

15. World Health Organization. Diet, nutrition and the prevention of chronic disease. Geneva: World Health Organization; 1990. (WHO Technical Report Series, 797).

16. Abrantes MM, Lamounier EAC. Prevalência de sobrepeso e obesidade nas regiões Nordeste e Sudeste do Brasil. Rev Assoc Med Bras (1992) 2003; 49:162-6.

17 Johnson GP, Castrillón FJD, Ospina S. Alteraciones nutricionales en adultos infectados por el virus de la inmunodeficiencia humana. Perspect Nutr Hum 2004; (12):23-37.

18. Ministério da Saúde. Boletim Epidemiológico AIDST 2010; Ano XXVII, $n^{\circ} .1$.

19. Gaulthier JHM, Cabral IE, Santos I, Tavares CMM. Pesquisa em enfermagem: novas metodologias aplicadas. Rio de Janeiro: Guanabara Koogan; 1998.

20. Programa Nacional de DST/AIDS, Secretaria de Vigilância à Saúde, Ministério da Saúde. Critérios de definição de casos de AIDS em adultos e crianças. Brasília: Ministério da Saúde; 2004.

21. Mocroft A, Kirk O, Barton SE, Dietrich M, Proenca $\mathrm{R}$, Colebunders R, et al. Anemia is an independent predictive marker for clinical prognosis in HIV-infected patients from across Europe. EuroSIDA study group. AIDS 1999; 13:943-50.

22. Feldman JG, Gange SJ, Bacchetti P, Cohen M, Young $\mathrm{M}$, Squires KE, et al. Serum albumin is a powerful predictor of survival among HIV-1-infected women. J Acquir Immune Defic Syndr 2003; 33:66-73.

23. Kirkwood BR, Sterne JAC. Essential medical statistics. 2nd Ed. Malden: Blackwell Science; 2003.

24. Gigante DP, Moura EC, Sardinha LMV. Prevalence of overweight and obesity and associated factors, Brazil, 2006. Rev Saúde Pública 2009; 43 Suppl:83-9.

25. Peixoto MRG, Benício MHD, Jardim PCBV. The relationship between body mass index and lifestyle in a Brazilian adult population: a cross-sectional survey. Cad Saúde Pública 2007; 23:2694-704.
26. Gigante DP, Barros FC, Post CLA, Olinto MTA. Prevalência de obesidade em adultos e seus fatores de risco. Rev Saúde Pública 1997; 31:236-46.

27. Jaime PC, Florindo AA, Latorre MRDO, Segurado AAC. Central obesity and dietary intake in HIV/ AIDS patients. Rev Saúde Pública 2006; 40:634-40.

28. Grinspoon S, Carr A. Cardiovascular risk and bodyfat abnormalities in HIV-infected adults. N Engl J Med 2005; 352:48-62.

29. Grinspoon S. Cardiovascular risk assessment, treatment vital for HIV patients on therapy. American Heart Association. Circulation 2009; 119:770-2.

30. Mulligan K, Harris DR, Monte D, Stoszek S, Emmanuel P, Hardin DS, et al. Obesity and dyslipidemia in behaviorally HIV-infected young. Clin Infect Dis 2010; 50:106-14.

31. Brown TT, Cole SR, Li X, Kingsley LA, Palella FJ, Riddler SA, et al. Antiretroviral therapy and the prevalence and incidence of diabetes mellitus in the multicenter AIDS cohort study. Arch Intern Med 2005; 165:1179-84.

32. Centers for Disease Control. Revision of the CDC surveillance case definition for acquired immunodeficiency syndrome. Council of State and Territorial Epidemiologists; AIDS Program, Center for Infectious Diseases. MMWR Morb Mortal Wkly Rep 1987; 36 Suppl 1:1S-15S.

33. Macallan DC. Nutrition and immune function in human immunodeficiency virus infection. Proc Nutr Soc 1999; 58:743-48.

34. Dworking MS, Williamson JM. AIDS wasting syndrome: trends, influence on opportunistic infections, and survival. J Acquir Immune Defic Syndr 2003; 33:267-73.

35. Sieleunou I, Souleymanou M, Schönenberger AM, Menten J, Boelaert M. Determinants of survival in AIDS patients on antiretroviral therapy in a rural centre in the Far-North Province, Cameroon. Trop Med Int Health 2009; 14:36-43.

36. Rousseau MC, Molines C, Moreau J, Delmont J. Influence of highly active antiretroviral therapy on micronutrient profiles in HIV-infected patients. Ann Nutr Metab 2000; 44:212-6.

37. De Luis DA, Bachiller P, Izaola O, Eiros Bouza JM, Aller R. Estado nutricional de pacientes infectados por el virus de la inmunodeficiencia humana (VIH). An Med Interna 2001; 18:619-23.

38. Vannucchi H, Unamuno MRDL, Marchini JS. Avaliação do estado nutricional. Medicina (Ribeirão Preto) 1996; 29:5-18.

39. Monteiro JP, Cunha DF, Cunha SFC, Santos VM, Silva-Vergara ML, Correia D, et al. Resposta de fase aguda, subnutrição e estado nutricional do ferro em adultos com AIDS. Rev Soc Bras Med Trop 2000; 33:175-80.

40. Terán-Rincón G, Solano L, Portillo Z. Indicadores nutricionales en pacientes infectados con virus de inmunodeficiencia humana. An Venez Nutr 2001; 14:27-34.

41. Marques MRO, Kondo K, Moares HAB. HIV/AIDS e suporte nutricional: efeitos da suplementação alimentar sobre o estado nutricional de homens. Invenio 2005; 8:143-54. 
42. Batista Filho M, Souza AI, Miglioli TC, Santos MC. Anemia e obesidade: um paradoxo da transição nutricional brasileira. Cad Saúde Pública 2008; 24 Suppl 2:247-57.

43. Subbaraman R, Devaleenal B, Selvamuthu P, Yepthomi T, Solomon SS, Mayer KH, et al. Factors associated with anaemia in HIV-infected individuals in southern India. Int J STD AIDS 2009; 20: 489-92.

44. Koethe JR, Heimburger DC. Nutritional aspects of HIV-associated wasting in sub-Saharan Africa. Am J Clin Nutr 2010; 91:1138S-42S

45. Oguntibeju OO, van den Heever WM, Van Schalkwyk FE. The interrelationship between nutrition and the immune system in HIV infection: a review. Pak J Biol Sci 2007; 10:4327-38.
46. Amorosa V, Synnestvedt M, Gross R, Friedman H, Macgregor RR, Gudonis D, et al. A tale of 2 epidemics: the intersection between obesity and HIV infection in Philadelphia. J Acquir Immune Defic Syndr 2005; 39:557-61.

47. Boodram B, Plankey MW, Cox C, Tien PC, Cohen $\mathrm{MH}$, Anastos K, et al. Prevalence and correlates of elevated body mass index among HIV-Positive and HIV-Negative Women in the Women's Interagency HIV Study. AIDS Patient Care STDS 2009; 23: 1009-16.

48. Brito AM, Castilho EA, Szwarcwald CL. Regional patterns of the temporal evolution of the AIDS epidemic in Brazil following the introduction of antiretroviral therapy. Braz J Infect Dis 2005; 9:9-19.

Submitted on $028 /$ Nov/2010

Final version resubmitted on 11/May/2011

Approved on 27/May/2011 